\title{
The Influence of Brand Trust and Religiosity on The Mudharabah Deposit Product Selection Decision
}

\author{
Prianda Pebri, Surya Bakti \\ STIE Muhammadiyah, North Sumatera, Indonesia \\ Email: prianda.pebri89@gmail.com, suryabakti14@gmail.com
}

\section{ARTICLE INFO}

Date received : 05-01-2022

Revision date : $10-01-2022$

Date received : 18-01-2022

\section{Keywords:}

Trust;

Religiosity;

Decision to choose

\section{ABSTRACT}

The purpose of this study is to analyze the influence of brand trust and religiosity on the decision to choose mudharabah deposit products in Islamic Commercial Banks. Population and sample are 100 respondents selected by accidental sampling in order to obtain research data through filling out a questionnaire. The results showed that partially or simultaneously the two independent variables consisting of brand trust and religiosity have a positive and significant effect on the decision to choose mudharabah deposit products in Islamic Commercial Banks.

\section{Introduction}

Competition among the existing banking world experienced by government, private, conventional and Islamic banks is happening very rapidly (Aziz \& Hendrastyo, 2020). All banks will offer various superior products and services in attracting new customers (Kartika et al., 2019). Furthermore, Indonesia as the largest Muslim country in the world is a potential market for banks to increase their market share. In particular, Islamic banking services are currently dominated by Muslims, although it does not rule out the possibility that other countries such as China, England, France are also interested in developing this system. Indonesia as the largest Muslim country in the world is a potential market for producers. Producers are aware that Muslim consumers are easy targets for marketing their products. One of the strategies they implement is Islamic Branding, which is to use Islamic identity in marketing their products (Santoso, 2019).

Recognizing the problem perceived by the customer and then looking for information and evaluating the product or service that best fits the perceived need is a process in a customer's decision making (Tjiptono, 2014). Purchasing decisions made by customers are one that is expected by the banking sector (Suprihati, Sumadi, \& Tho'in, 2021). The decision to choose Islamic products for new prospective customers will require a lot of consideration (Masitoh, Wibowo, \& Sunaryo, 2018). For a customer who has good experience and knowledge of sharia products, of course choosing sharia banking is not a problem (Putri, Solihat, Rahmayani, Iskandar, \& Trijumansyah, 2019). So for prospective customers who do not have a good understanding of Islamic bank products, of course, the Islamic banking sector must work more in promoting and introducing it to the wider community (Hasanah, 2019).

Trust is a strong reason for a customer to choose Islamic banking products (Saputro \& Lataruva, 2010). A good trust will add a sense of customer confidence in a brand (Lestari, 2019). Brand trust must be maintained for banks in building a sense of comfort to their customers (Mujaddid \& Nugroho, 2019). Banks will continue to strive to provide the best for their customers with

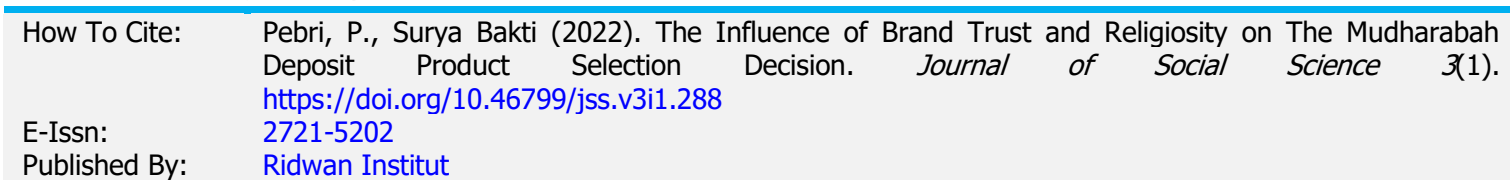


the aim that there will be no complaints resulting from products or services that are not as expected (Andriani \& Halmawati, 2019). Customer trust in a banking product or service has an impact on the decision to choose various other products in banking (Tamindael \& Ruslim, 2021). Therefore, building high trust in customers is a priority for creating a sense of customer trust in the bank. Through the level of trust that is built between the bank and the customer, it is very possible that the banking business to be run will be easily built more intensively between the customer and the bank, considering that the bank is obliged to build a high sense of trust in its customers so that customers feel confident and safe when saving money at the bank (Aziz \& Hendrastyo, 2020).

Religiosity is basically an act of someone who is related to the wider community in order to develop the creativity of devotion (worship) to Allah alone (Tamindael \& Ruslim, 2021). Customers who have a good level of religiosity will encourage them to prefer products or services that are in accordance with their belief values (Imamuddin, Syahrul, \& Dantes, 2020). The customer decides to keep the Islamic bank in relation to the issue of faith and belief in the prohibition of usury for Muslims, while the rational factors in the form of knowledge, product quality and service quality that customers understand are factors that influence customer preferences in choosing Islamic banks (Hasanah, 2019).

\section{Method}

This research belongs to the quantitative type. As for the object of research, namely Sharia Commercial Banks in Kisaran City. Furthermore, 100 respondents were selected by accidenting sampling to be the population and research sample. The data collection technique used a questionnaire with a Likert model scale. Data analysis used multiple linear regression analysis with the help of SPSS 22 application program.

\section{Results And Discussion Multiple Linear Regression Analysis}

The results of multiple linear regression analysis can be seen in the Table 1 .

Table 1

Results of Multiple Regression Analysis Coefficients ${ }^{a}$

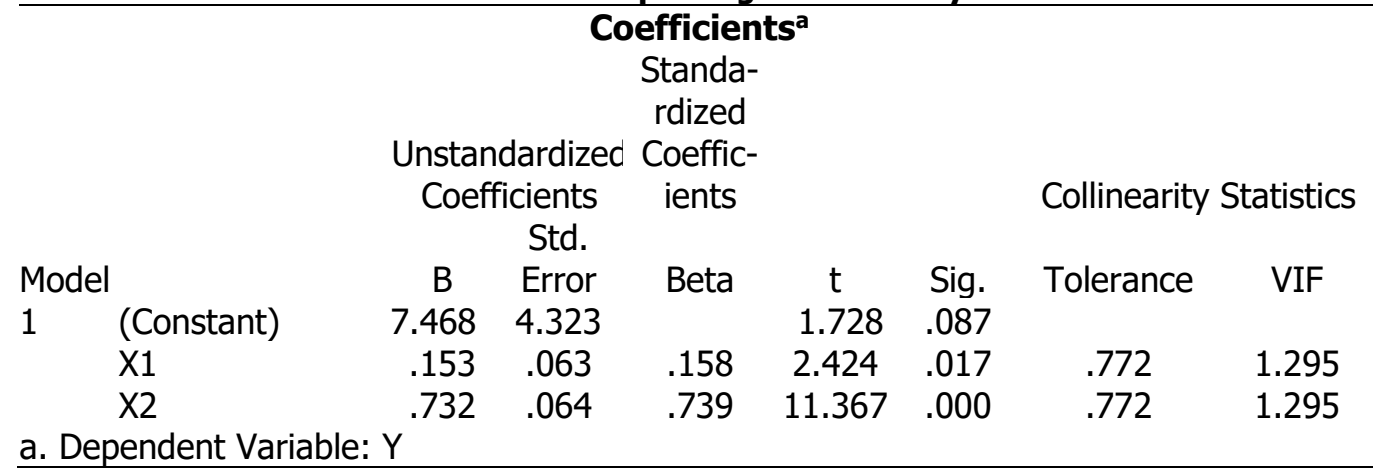

Based on Table 1, the multiple linear regression equation in this study is: $Y=7,468$ $+0,153 \mathrm{X} 1+0,732 \mathrm{X} 2+0,452 \mathrm{X} 3+\mathrm{e}$

1 ) In this regression model, the listed constant value of 7.468 can be interpreted that if the independent variable in the model is assumed to be zero, on average the variables outside the fixed model will increase the decision to choose a fixed mudharabah deposit product by 7.468 one-unit or in words On the other hand, if the brand trust and religiosity variables are not increased, then the decision to choose the mudharabah deposit product is still 7,468 units. 
2) The regression coefficient value of 0.153 in this study means that when the brand trust has increased by one unit, it will increase the decision to choose mudharabah deposit products by 0.153 units.

3) The value of the regression coefficient b2 is 0.732 in this study, which means that the religiosity variable is 0.732 which indicates that when religiosity has increased by one unit, it will increase the decision to choose mudharabah deposit products by 0.732 units.

\section{Partial Test (t test)}

Based on table 1, it is known that the results of the $t$ test (partial) are involve:

1) The significance value for the brand trust variable $(0.017)$ is smaller than that of $5 \%$ alpha $(0.05)$ or $t$ count $=2.424>t$ table $1.985(\mathrm{n}-\mathrm{k}=100-3=97)$. Based on the results obtained, $\mathrm{HO}$ rejects and accepts. $\mathrm{Ha}$ for brand trust variable. Thus, partially that the brand trust variable has a positive and significant effect on the decision to choose a mudharabah deposit product.

2) The significance value for the location variable $(0,000)$ is smaller than that of $5 \%$ alpha $(0.05)$ or $\mathrm{t}$ count $=11,367>\mathrm{t}$ table $1,985(n-k=100-3=97)$. Based on the results obtained, $\mathrm{HO}$ rejects and accepts. $\mathrm{Ha}$ for the religiosity variable. Thus, partially that the religiosity variable has a positive and significant effect on the decision to choose mudharabah deposit products.

\section{Simultaneous Test (Test F)}

The results of the $F$ test in this study can be seen in Table 2.

Table 2

F Test Results ANOVA $^{a}$

\begin{tabular}{lrrrrr}
\hline Model & \multicolumn{1}{c}{ Sum of } & \multicolumn{4}{c}{ Mean } \\
\hline 1 & Squares & df & Square & \multicolumn{1}{c}{$\mathrm{F}$} & \multicolumn{1}{c}{ Sig. } \\
\hline Regression & 1811.346 & 2 & 905.673 & 104.547 & $.000^{\mathrm{b}}$ \\
$\quad$ Residual & 840.294 & 97 & 8.663 & & \\
\multicolumn{1}{l}{ Total } & 2651.640 & 99 & & & \\
\hline
\end{tabular}

a. Dependent Variable: $Y$

b. Predictors: (Constant), X2, X1

In the regression test results in this study, it is known that the significance value is 0.000 . Where the required significance value of $F$ is less than $5 \%$ or 0.05 or the value of Fcount $=104.547>$ Ftable $3.09(\mathrm{df} 1=\mathrm{k}-1$ $=3-1=2)$ while $(\mathrm{df} 2=\mathrm{n}-\mathrm{k}(100-3=97$ Thus it can be concluded that all independent variables, namely brand trust and religiosity, have a positive and significant effect on the decision to choose mudharabah deposit products.

\section{Coefficient of Determination (R2)}

The results of the determination test can be seen in Table 3.

Table 3

Determination Coefficient Test Results

\begin{tabular}{llrrrr}
\hline \multicolumn{6}{c}{ Model Summary $^{\mathbf{b}}$} \\
\hline Model & R & R Square & $\begin{array}{c}\text { Adjusted R } \\
\text { Square }\end{array}$ & $\begin{array}{c}\text { Std. Error of the } \\
\text { Estimate }\end{array}$ \\
\hline 1 & $.827^{\mathrm{a}}$ & .683 & .677 & 2.943 \\
\hline
\end{tabular}

a. Predictors: (Constant), X2, X1

b. Dependent Variable: $Y$ 
Based on the table above, the correlation regression value is 0.827 , which means that brand trust and religiosity together with the decision to choose mudharabah deposit products have a strong contribution to the level. For more than one independent variable it is good to use adjusted R Square. Where the value (R2) is $0.677(67.7 \%)$. So it can be said that $67.7 \%$ of the variation in the dependent variable, namely brand trust and religiosity in the model, can explain the variables towards the decision to choose mudharabah deposit products, while the remaining $32.3 \%$ is influenced by other variables outside the model.

\section{The Effect of Brand Trust on Choosing Decisions}

The results of previous studies stated that brand trust has a positive and significant effect on the decision to choose a customer (Arif, 2020; Masitoh et al., 2018; Nasib, Syaifullah, \& Daulay, 2021). However, this study is not in line with the research conducted by (Aziz \& Hendrastyo, 2020) which stated that brand trust has no influence in increasing the decision to choose. The results of this study indicate that brand trust has a positive and significant effect on the decision to choose a mudharabah deposit product for Islamic Commercial Banks. The trust of a customer will be better when banks are able to provide satisfaction with the products and services that have been promised (Nasib, 2021; Lestari \& Nasib, 2019). Thus, that the potential for complaints from customers.

\section{The Effect of Religiosity on Voting Decisions}

The results showed that religiosity had a positive and significant effect on the decision to choose. This result is in accordance with previous research which states that religiosity has a positive and significant effect on the decision to choose a mudharabah deposit product for Islamic Commercial Banks (Tamindael \& Ruslim, 2021; Mujaddid \& Nugroho, 2019; Hakim, 2021). The findings in this study that customers who have a good level of religiosity will have an open attitude in accepting products from Islamic banking.
The Influence of Brand Trust and Religiosity on Voting Decisions.

The results showed that new trust and religiosity have a positive and significant effect on the decision to choose mudharabah deposit products in Islamic Commercial Banks. This result is in line with previous research which states that increasing purchasing decisions by a consumer can be done by maximizing the existing trust in consumers and the level of religiosity (Rinuastuti, Darwini, Agustiani, \& Andilolo, 2018; Abror, 2019; Casriyanti, 2020). This shows that when brand trust and religiosity get better, it will have an impact on increasing a customer's purchasing decision in choosing Islamic products.

\section{Conclusion}

Based on the results of the research and discussion above, the conclusions in this study include:

First is, partially, brand trust has a positive and significant effect on the decision to choose mudharabah deposit products at Islamic Commercial Banks.

Second, partially religiosity has a positive and significant effect on the decision to choose mudharabah deposit products at Islamic Commercial Banks.

Third, simultaneously, brand trust and religiousity have a positive and significant effect on the decision to choose mudharabah deposit products in Islamic Commercial Banks.

\section{References}

Abror, Rahmatulloh1Yasri2Abror. (2019). The Influence of brand image and perceived quality on brand loyalty with brand trust as mediator in PT Bank Syariah Mandiri. Google Scholar

Andriani, Gicella Fanny, \& Halmawati, Halmawati. (2019). Pengaruh Bagi Hasil, Kelompok Acuan, Kepercayaan Dan Budaya Terhadap Minat Menjadi Nasabah Bank Syariah. Jurnal Eksplorasi Akuntansi, 1(3), 1322-1336. Google Scholar

Arif, Mohammad Sony Zakiyuddin. (2020). Pengaruh Kepercayaan Terhadap Loyalitas Nasabah Melalui Kepuasan Sebagai Variabel Intervening Produk Tabungan Emas Pegadaian. Jurnal IImu Manajemen (JIM), 8(2). Google Scholar 
Aziz, Nazzarudin, \& Hendrastyo, Vito Shiga. (2020). Pengaruh Kualitas Layanan, Kepercayaan dan Promosi Terhadap Minat Nasabah Menabung Pada Bank Syariah Cabang Ulak Karang Kota Padang. Jurnal Pundi, 3(3), 227-234. Google Scholar

Casriyanti, Casriyanti. (2020). Pengaruh Religiusitas, Consumer Knowledge dan Brand Image terhadap Keputusan Menjadi Nasabah pada Bank Syariah. Jurnal Tasyri': Jurnal Muamalah Dan Ekonomi Syariah, 2(1), 5270. Google Scholar

Hakim, T. I. (2021). Pengaruh Pengetahuan Perbankan Syariah Dan Religiusitas Terhadap Minat Berkarir Diperbankan Syariah Dengan Sikap Sebagai Variabel Moderasi. JIMAT (Jurnal IIm. Mhs. Akuntansi), 1037-1045.

Hasanah, Fadhilatul. (2019). Pengaruh Tingkat Religiusitas, Pengetahuan, Kualitas Produk dan Kualitas Pelayanan Terhadap Preferensi Menabung Mahasiswa Universitas Muhammadiyah Palembang Pada Bank Syariah. BALANCE: JURNAL AKUNTANSI DAN BISNIS, 4(1), 485-495. Google Scholar

Imamuddin, M., Syahrul, Syahrul, \& Dantes, Raymond. (2020). Pengaruh Label Halal Dimoderasi Religiusitas Terhadap Keputusan Pembelian Produk Kemasan oleh Mahasiswa PTKIN Se-Sumatera Barat. KABILAH: Journal of Social Community, 5(1), 14-25. Google Scholar

Kartika, Chandra, Yusuf, Yusuf, Hidayat, Fauzi, Krinala, Efina, Fauzi, Slamet Nur, Sari, Anggun Puspita, Firmansyah, Eggy, \& Wahyudi, Wahyudi. (2019). Pengaruh Religiusitas, Trust, Corporate Image, Dan Sistem Bagi Hasil Terhadap Customer Behavior Intention Menabung dan Customer Loyalty di Bank Syariah Mandiri Jawa Timur. Management \& Accounting Research Journal Global, 4(1). Google Scholar

Lestari, I. E., \& Nasib. (2019). Trust Identification And Smartphone Purchase Decisions (Structural Equation Modeling Approach). [19] S. C. A. S. A.; I. E. Indawati Lestari; Nasib, "Trust IdentificaInternational Journal of Civil Engineering and Technology (IJCIET), 10.

Lestari, N. (2019). Dasar Pemasaran. Yogyakarta: Deepublish.

Masitoh, Martina Rahmawati, Wibowo, Hermansyah Andi, \& Sunaryo, Deni. (2018).
Pengaruh Kualitas Pelayanan, Kepuasan, Dan Kepercayaan Merek Terhadap Niat Pembelian Ulang Di Toko Online Tokopedia. Jurnal Manajemen, \&(1).Google Scholar

Mujaddid, Fajar, \& Nugroho, Pandu Tezar Adi. (2019). Pengaruh pengetahuan, reputasi, lingkungan dan religiusitas terhadap minat pelajar Sekolah Menengah Kejuruan prodi perbankan Syariah dalam menabung di bank Syariah. Jurnal Ekonomi Islam, 10(1), 14-37. Google Scholar

Nasib, S. (2021). Meningkatkan Keputusan Pembelian Melalui Kualitas Produk, Promosi dan Kepercayaan pada PT. Weedo Niaga Global. Ekuivalensi, vol. 7, no. 1, 48-57

Nasib, Nasib, Syaifullah, Syaifullah, \& Daulay, Zulia Rifda. (2021). Memaksimumkan Brand Loyalty, Brand Trust Dan Brand Image Melalui Satisfaction. JURNAL EKUIVALENSI, オ1), 38-47. Google Scholar

Putri, Yulia, Solihat, Ani, Rahmayani, Rani, Iskandar, Iis, \& Trijumansyah, Andry. (2019). Strategi meningkatkan minat menabung di Bank Syariah melalui penerapan religiusitas. Jurnal Manajemen Dan Bisnis (Performa), 16(1), 77-88. Google Scholar

Rinuastuti, Baiq Handayani, Darwini, Sri, Agustiani, Eka, \& Andilolo, Imanuella Romaputri. (2018). Pengaruh Religiusitas Terhadap Perilaku Memilih Bank Syariah Melalui Kepercayaan Merek (Studi Pada Nasabah Bank Syariah di Kota Mataram). DistribusiJournal of Management and Business, 6(2), 47-59. Google Scholar

Santoso, Imam. (2019). Branding Islam dan Religiusitas Individu Pada Keputusan Nasabah Dalam Menggunakan Produk Bank Syariah. BASKARA: Journal of Business and Entrepreneurship, 2(1), 1-12. Google Scholar

Saputro, Ropinov, \& LATARUVA, Eisha. (2010). Analisis pengaruh kualitas produk, kualitas pelayanan, dan kepercayaan pelanggan terhadap loyalitas pelanggan (studi pada PT. Nusantara Sakti Demak). Universitas Diponegoro. Google Scholar

Suprihati, Suprihati, Sumadi, Sumadi, \& Tho'in, Muhammad. (2021). Pengaruh Religiusitas, Budaya, Pengetahuan Terhadap Minat Masyarakat Menabung di Koperasi Syariah. Jurnal Ilmiah Ekonomi Islam, ス1), 443-450. Google Scholar 
Tamindael, Mauwelles, \& Ruslim, Tommy Setiawan. (2021). Pengaruh Komunikasi Dan Citra Merek Terhadap Loyalitas Merek Dengan Kepercayaan Sebagai Mediasi. Jurnal Manajerial Dan Kewirausahaan, 3(1), 236244. Google Scholar
Tjiptono, Fandy. (2014). Pemasaran Jasa-Prinsip. Penerapan, Dan Penelitian, Andi Offset, Yogyakarta. Google Scholar

\section{Copyright holder:}

Prianda Pebri, Surya Bakti (2022)

First publication right:

Journal of Social Science

This article is licensed under:

(c) 